\title{
レヴァント鉄器時代の鉢形土器に見る アッシリアの影響について \\ Considering the Neo-Assyrian Influence on Ceramic Bowls from the Iron Age Levant
}

\author{
足立拓 朗 \\ ADACHI Takurou
}

\begin{abstract}
The aim of this paper is to examine how the expansion of NeoAssyrian Empire had influenced the local material culture in the Levant from the 9th to 7 th century B. C. The case study consists of 4 types of ceramic bowls: carinated bowls with everted rim, shallow bowls with sharp carination, bar-handled bowls and loop-handled bowls. The distribution of carinated bowls with everted rim and shallow bowls with sharp carination type 1 can be seen in Northern Mesopotamia. The distribution of shallow bowls with sharp carination type 2 , bar-handled bowls and loop-handled bowls can be seen in the Levant. Their distribution patterns and their classifications reveal that the Neo-Assyrian Empire did not give a strong influence to local pottery assemblages. Based on the analysis, the only important Assyrian sites in the Levant had carinated bowls with everted rim. Tell Mastuma, which is one of the Iron Age II sites in the northwestern part of Syria, is located on the way of the Assyrian expansion to west. The bowls unearthed from Tell Mastuma should be designated as a part of the Levantine material cultures.
\end{abstract}

\section{I.はじめに}

前 9 ～ 7 世紀のレヴァント地方（シリア・パレスチナ）には多くの小国家が乱立し, 多様な物質文化が育まれた。だが, それらの小国家は徐々にアッシリアに征服されていっ た。その過程で物質文化はいかに変容していったのだろうか。それを分析することによ り，アッシリアがどのように広域国家として成立していったのかを明らかにしていきた い。しかし, その目的を達成するために, 鉄器時代の多様な物質文化全般を検証するこ とは困難であり，また個別の物質文化の研究も進んではいない。

本稿では鉄器時代物質文化の個別研究の一つとして, レヴァントと北メソポタミアに おける鉢形土器の分類と分布による分析をおこなう。併せて，(財) 古代オリエント博物

* 中近東文化センター

Middle Eastern Culture Center in Japan 
館が調査したマストゥーマ (Mastuma) 遺跡の性質について, 本稿による鉢形土器の分 析から考察する。この 2 点から前 $9 \sim 7$ 世紀のレヴァントと北メソポタミアの物質文化 の一端を明らかにし，レヴアント地方におけるアッシリアの影響について考えてみたい。 マストゥーマはシリア北西部に位置し，アッシリアのレヴァント侵攻の際の進路上に位 置している。そのため，アッシリアの征服の影響を何らかの形で被ったと考えられる。

\section{II. 分析対象の鉢形土器}

前 9 〜 世紀のレヴァント地方には様々な土器群が存在していた。この地方の土器研 究はアミラン (R. Amiran) によってまとめられておりり，近年リーマン (G. Lehmann) によってシリア地域の土器編年研究も行われている。また, マストゥーマ資料を中心と した和田久彦の研究, 斎藤信弘の北シリアにおける搬入土器を中心とした研究, 四角隆 二によるレヴァント地方におけるケルノス形土器 (Kernos) の研究，筆者の坏形土器の (6) 研究等がおこなわれており，日本においても近年活発な研究対象となりつつある。この 時期の北メソポ夕ミアの土器群については, オーツ (J. Oates) とリネス (J. Lines)によっ てまとめられている。最近はカーティス (J.Curtis) らの発掘調查によって新資料が追加 されつつある。また大津忠彦はアッシリアの典型的な土器群の一つであるパレス・ウエ ア (Pallace Ware) の分布を明らかにした。

本稿では北メソポタミアとパレスチナにその分布の中心を有すると考えられる鉢形土 器 4 種類を抽出して分析の対象とする。当然, これら 4 種類の他にも各種の鉢形土器が 存在するのであるが, レヴァント地方へのアッシリアの拡大状況を捉えることができる 鉢形土器としてこれら 4 種類を選択した。その理由をそれぞれの器形について述べる。 その後, それらの分布を明らかにし，考察の材料としたい。

2-1. 口縁外屈鉢（Carinated Bowls with Everted Rim）（第1困）

この器形は，リネスによってニムルード (Nimrud) 出土の後期アッシリアの鉢形土器 の一つとして認定され，その時期はサルゴンII世の治世までは遡ると示唆された。比較 的高めで「八」の字状に開く高台を有し，口縁部は外屈し，口縁部直下がくびれてから 胴部へいたる。そのため，肩部のような屈曲部，つまり竜骨部（Carination）を有する。 この器形の土器はリネスによって後期アッシリアの鉢形土器の最も一般的なものである と示唆された。オーツはフォート・シャルマネセル (Fort Shalmaneser) における分析 でも, この器形が最も一般的であると述べている。この器形の土器は後期アッシリアに おける特徵的な物質文化の一つとみなすことができ，そのためアッシリアの征服地にお いても使用された可能性が強いと仮定できる。 


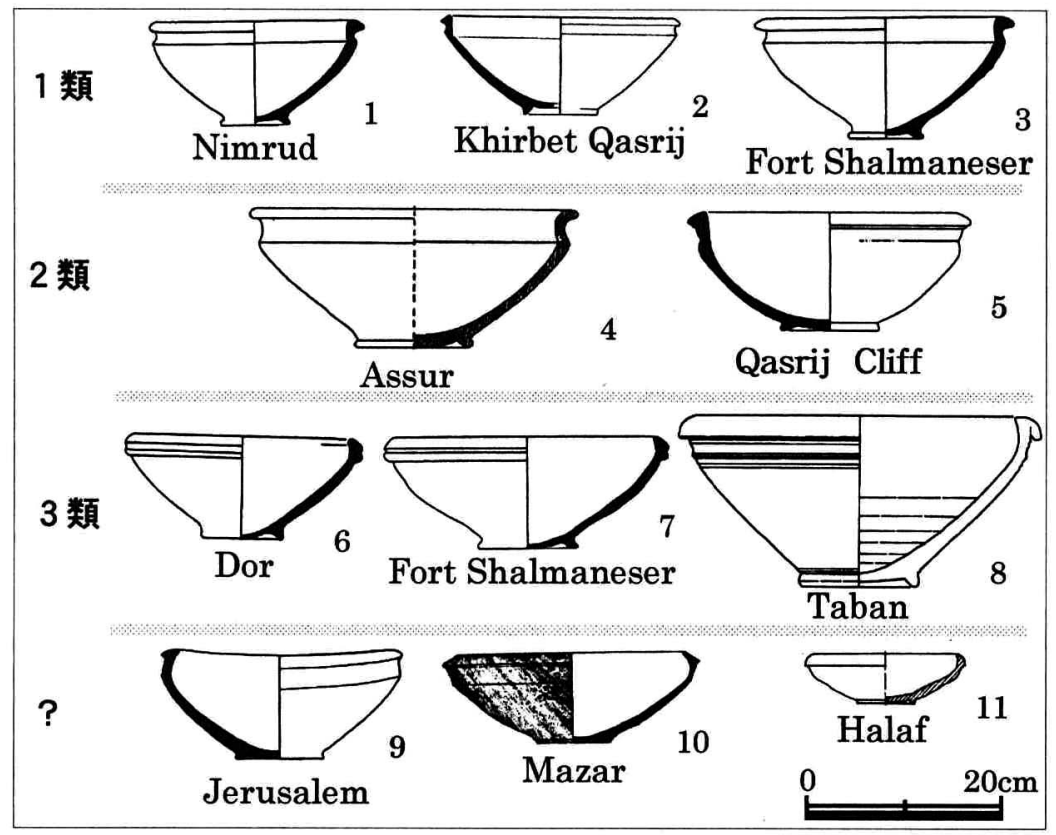

第1図 口縁外屈錸（Carinated Bowls with everted Rim）

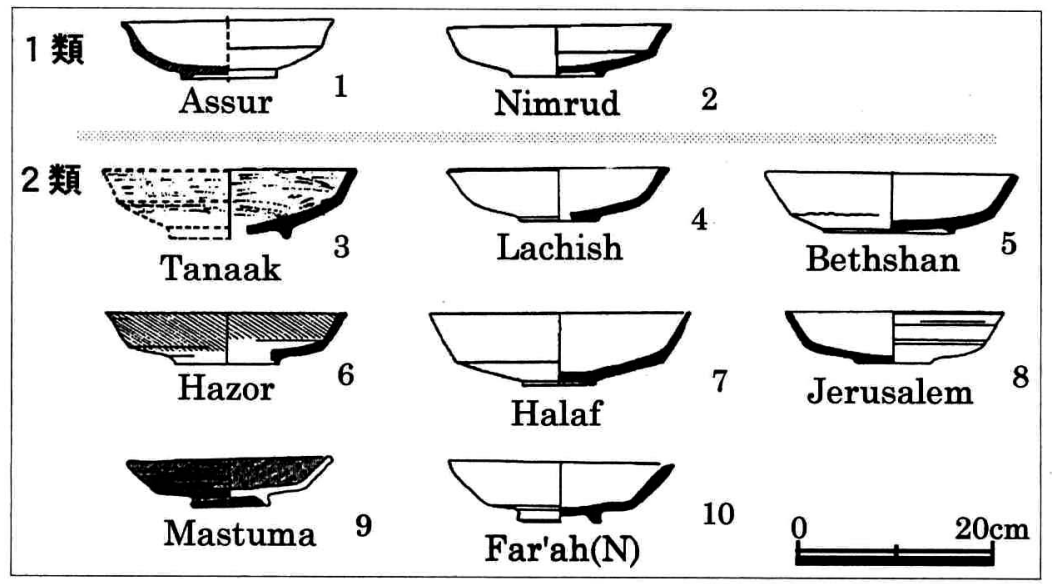

第 2 図胴部屈曲浅鉢（Shallow Bowls with Sharp Carination) 
2-2. 胴部屈曲浅鉢（Shallow Bowls with Sharp Carination）(第 2 図)

上記の口縁外屈鉢と同じように，オーツに後期アッシリアの鉢形土器の一器形として 認定され, 特に前 7 世紀に属すると示唆されている。リーマンはこの器形を含む土器群 をアッセンブリッジ 4 (Assemblage 4) と命名し，その時期を前650-580年としている。

器高は比較的低く, 皿状を呈し, 胴部に明確な屈曲部を有することが特徵である。口 縁部は外傾して直線的，あるいはわずかに外反して立ち上がり，口唇部は丸くおさまる。 この器形の土器は後期アッシリアの特徵を示すとともに，シリア北西部に位置するマス トゥーマでも出土しており，その分布の意味が注目に值すると判断して分析対象とした。 マストゥーマでの出土はアッシリアの影響をこの遺跡の土器文化が被ったことを示して いるのだろうか。

\section{2-3. 棒状把手付鉢（Bar-Handled Bowls）（第 3 困）}

この器形はアミランによって, 鉄器時代 IIA-B 期（前1000-800年頃）から現れ, 鉄器 時代 IIC 期（前800-587年頃）まで続いていると分析されている。アミランの集成は北部 すなわちイスラエル王国にこの器形が分布していることを示している。低めの高台を有 し, 器高も比較的低い。口縁部は直立するものが一般的で, 口唇部は丸みを帯びた方形 で作られている。

アミランは金属器を模倣した土器の研究が, この器形の土器の起源を探る上で必要で あると示唆しているので, この器形の土器の起源が金属器にあると想定していたようで ある。

この器形の土器はマストゥーマでは報告例はないが, 同じく北西シリアに位置するア ブ・ダンネ (Abou Danné)，アフィス (Afis) で出土している。主にパレスチナに分布 すると考えられるこの夕イプの土器は, 北西シリアでも発見されている。さらに北メソ ポタミアにもこの器形が分布しているのかを検討する必要があるだろう。

2-4. ループ状把手付鉢（Loop-Handled Bowls）（第 4 図）

棒状把手付鉢と同じくアミランによって集成されており, 鉄器時代 IIC 期に位置づけ られ，南パレスチナに分布していると示唆されている。低めの高台を有するものと，無 高台のものがあり, 胴部は半球状を呈する。口唇部からループ状の把手が垂直方向に 1 対あるいは 2 対付けられる。マストゥーマからもこの器形の土器が出土している。アミ ランの集成で示されているように，この器形の土器が南パレスチナに分布するのか，ま た，マストゥーマ出土の同種の土器とはパレスチナとどのような関係にあるのかを分析 する。 


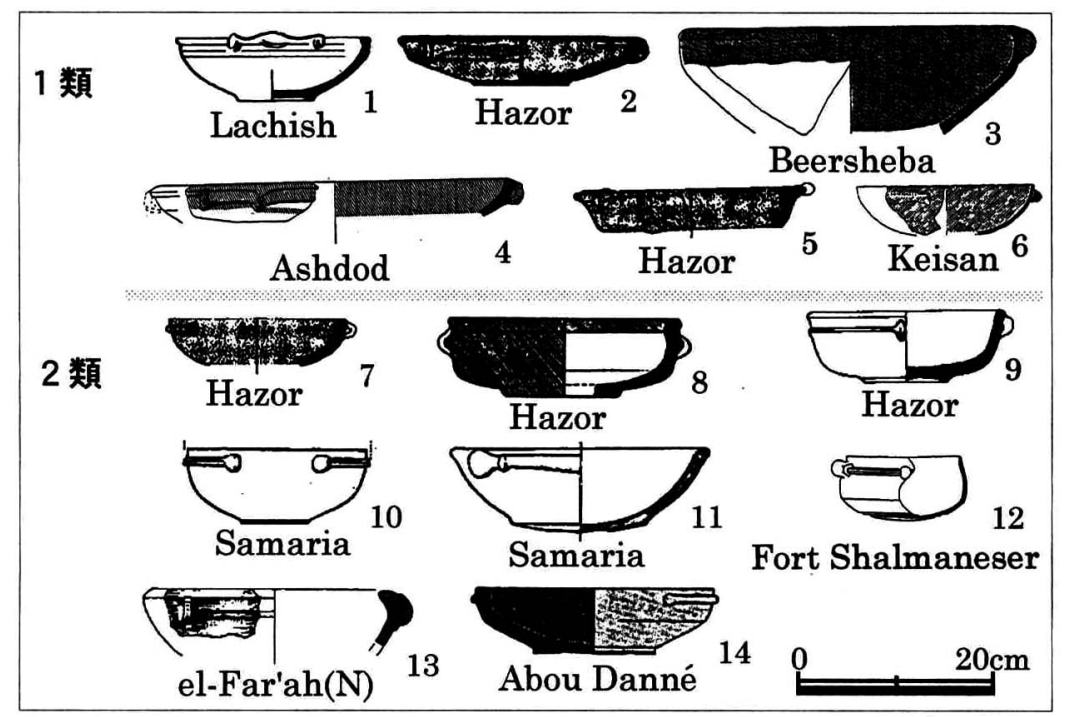

第 3 図 棒状把手付鉢（Bar-Handled Bowls）

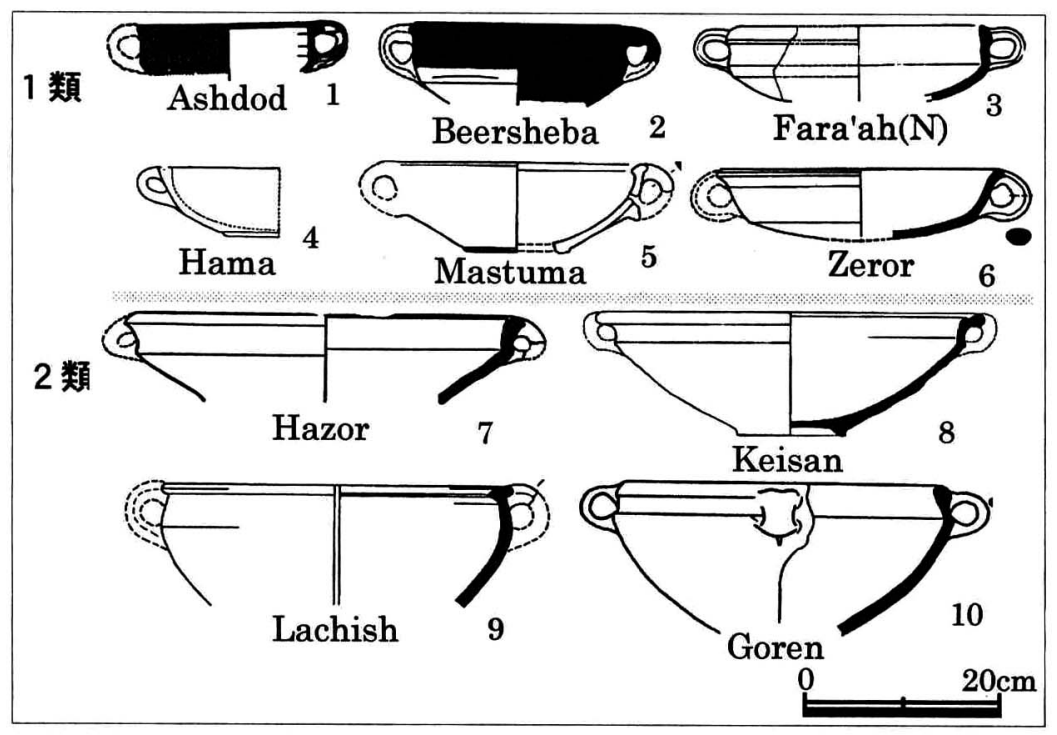

第 4 困 ループ状把手付鉢（Roop-Handled Bowls） 


\section{III. 鉢形土器の分布}

本稿で分析対象とした 4 器形は二つのグループに分けられる。すなわち, 北メソポ夕 ミアにその分布の中心があり，アッシリアに属すると考えられる口縁外屈鉢と胴部屈曲 浅鉢のグループと, パレスチナに分布の中心がある棒状把手付鉢とループ状把手付鉢の グループである。これらの土器群が地理的にその中間に位置するシリア地方でどのよう な分布を示すのか, またその分布がどのように変遷するのかを中心に分析していく。

\section{3-1. 口縁外屈鉢の分布と分類（第 1 図）}

口縁外屈鉢は，アッシリアの中心地であるニムルード，フォート・シャルマネセルで 出土しており，前 $8 ７$ 世紀頃に属すると考えられる（第 1 図 1,3 ）。 チグリス河を遡ったカスリジ・クリフ (Qasrij Cliff), キルベト・カスリジ (Khirbet Qasrij)，キルベト・カツニエ (Khirbet Khatuniyeh)，スゥェイジ（Thuwaij）でも出土 しており，(第 1 図 2，5），スゥェイジ以外は前 7 世紀後半以降頃と考えられる。

アッシュール (Assur) ではこの器形の土器が隹棺の蓋として利用されており(第 1 図 $4)$, 同じく隹棺の蓋として利用された鉢形土器がハブール河左岸のタバン (Taban) で も発見されている(第1図 8 )。ただ両者の器形は口縁部の作りが異なっており, タバン 出土資料のほうがやや法量が大きい。夕バンの対岸に位置するクネイデジ (Kneidej) で は底部が平底状を呈する口縁外屈鉢が出土しているが, このタイプの底部を有する口縁 外屈鉢はリマー（Rimah）の中期アッシリア期からも出土している。リマーの後期アッ シリア期からは高台を持つ口縁外屈鉢が出土していることから, 平底状の口縁外屈鉢が 先に出現していたと考えられる。

口縁外屈鉢は口縁の外屈が強い夕イプ（1 類）（第 1 困 1 〜 3) と弱い夕イプ（2 類） (第 1 図 4, 5), 口縁部が外屈というよりむしろ外折し, くびれや肩部（竜骨部： Carination) が見られない夕イプ $(3$ 類) (第 1 図 6 ～- $)$ に分類できる。 2 類は前 7 世 紀後半以降の遺跡で検出例が多く, 1 -3 類は前 7 世紀後半以降と考えられる遺跡から は検出例が少ない。

さて, この口縁外屈鉢の北メソポタミア以外での出土例であるが，まずシリアではア (24) フィスから 2 類が出土している。パレスチナにおいてはドル (Dor)において 3 類が出土 している(第1図 6)。パレスチナでは, イェルサレム (Jerusalem), マザール (Mazar) で同様な鉢形土器が見つかっている。イェルサレムの資料は底部が丸みを帯びるという 類似性は認められるものの, 口縁部の外屈は弱く, また肩部の張りも明瞭でない, 2 類 の形態に近い資料と言えるが，時期が前 8 世紀頃とやや古くなる。マザールの資料は形 態は似ているが平底を呈しており，北メソポ夕ミアの口縁外屈鉢とは異なる。北東シリ アのハラフ (Halaf) の資料は小型であり, 底部が平底状を呈することからクネイデジや 


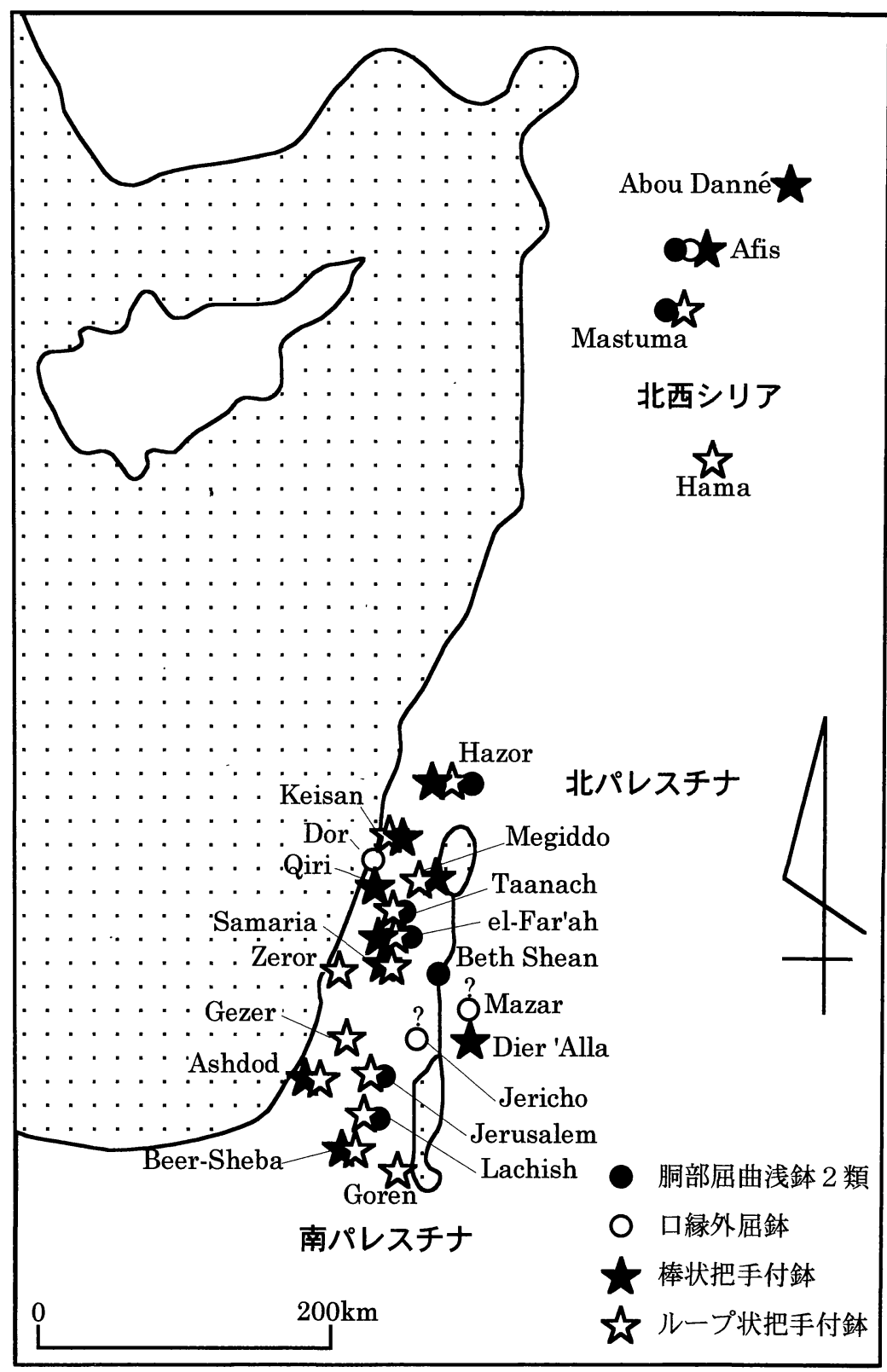

第 5 図 レヴァント地方鉢形土器分布図 


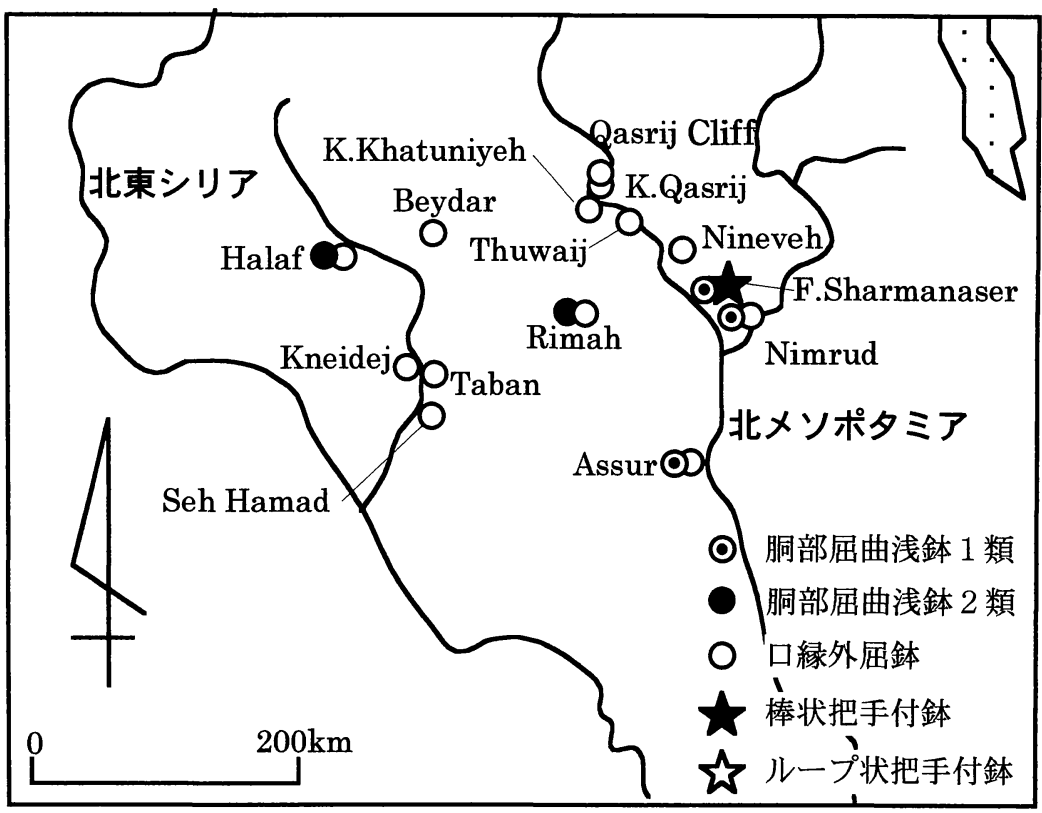

第 6 図 北メソポタミア地方鉢形土器分布図

リマー出土資料に似ている。イェルサレム，マザール，八ラフの資料は真性の口縁外屈 鉢とは言えないが何らかの影響を受けた土器群である可能性がある。

口縁外屈鉢の分布はシリアではアフィス，パレスチナではドルで例外的に出土例が認 められるが，分布の中心はあくまで北メソポ夕ミアである(第 $5 \cdot 6$ 図)。

\section{3-2. 胴部屈曲浅鉢の分布と分類（第 2 図）}

胴部屈曲浅鉢は口縁部がやや外反して立ち上がるタイプ（1類）(第 2 図 1，2）と直 線的に外傾して立ち上がる夕イプ（2 類）(第 2 図 3 10) に分けられる。1 類は北メソ ポタミアに分布し，2 類は北東シリアからパレスチナに分布している（第 5 ・6図）。管 見によれば， 2 類には前10世紀後半まで遡る資料が存在しているが， 1 類は前 9 世紀に 属する資料さえ確認できない。この結果は, 北メソポタミアに前 9 ～ 8 世紀の調査遺跡 が少ないことに原因がある。そのため， 2 類が 1 類に先行するかどうか，あるいは両者 が何らかの系統関係を有するかどうかは明確にはしえない。全く異なる系統関係を有し ている可能性もある。

\section{3-3. 棒状把手付鉢の分布と分類}

アミランは棒状把手付鉢が，棒状把手の短いタイプと長いタイプに分けられる可能性 を示唆した。棒状把手の両端には膨らみが見られ, 全体としては横に長い「H」字状を 
呈する。中には中央部も若干膨らんでいるものもある。棒状把手が付けられている位置 は口唇部直下である場合と口唇部から少し下である場合がある。

これらの特徵を総合すると, 把手の長さが短く, 中央部に膨らみを持ち, 口唇部直下 に付けられるタイプ（1 類）（第 3 図 1 ～6 ）と把手が長く，中央部に膨らみを持たず, 口唇部よりやや下に付けられるタイプ（2 類）（第 3 図 7 ～14）に分類できる。

1 類は前10〜8世紀に属しており，2 類は前 8 世紀に属しているようだ。ただ，ケイ サン (Keisan) の資料は把手は短く，中央に膨らみを有するという 1 類の特徴を有する が，把手は口唇部直下に付けられてはいない（第 3 図 6 )。またアシュドド (Ashdod)の 資料は把手は短く, 口唇部直下に付けられているが，中央部には膨らみがない（第 3 図 $4)$ 。ケイサンとアシュドドの資料は 1 類としては例外的なものに位置づけられ, 分類上 は矛盾している言えよう。時期的には両者とも，前10～ 8 世紀に含まれている。現時点 では, 1 類から 2 類へ棒状把手付鉢が型式変化していくものと仮定し,ケイサンとアシュ ドドの資料は 1 類から 2 類への中間形態として理解し，1類の範疇に入れておく。

1 類の分布は, 南パレスチナのベールシェバ (Beersheba), エル・ファルア (南) (ElFar'ah(S))，ラキシュ (Lachish) を中心とする。2 類になるとサマリア (Samaria), エル・ファルア (北), ハツォール (Hazor), メギド (Megiddo) 等の北パレスチナに分 布が広がる。2 類は北西シリアのアフィス, アブ・ダンネでも出土している（第 3 図14）。 また北メソポタミアのフォート・シャルマネセルでも出土している（第 3 図11）。この資 料とサマリアの資料（第 3 図12）の棒状把手は棒状把手端部の膨らみの内側にもう一つ 膨らみを有する特殊なタイプである。

北メソポタミアでは，フォート・シャルマネセルしか出土例を探し出すことが出来な かったが，北メソポ夕ミアで 1 例だけというのは，特殊な分布状況であり，今後さらに 検討していかなければならない。ただ北メソポタミアに分布する棒状把手付鉢が非常に すくないことは指摘できるだろう。

3-4. ループ状把手付鉢の分類と分布

ループ状把手付鉢には，器高の高い夕イプ（1 類）（第 4 図 1 - 6 ）と低い夕イプ (2 類）(第 4 図 7 10) に分類が可能である。1 類については鉄器時代 I 期に遡る類例も存 在する。前 9 〜 世紀においてはシリアからパレスチナの広い範囲に分布する。北メソ ポタミアには分布は及ばないであろう。

1 類は, いわゆる「クラテル」形土器との区別が明確ではない。元来ギリシア陶器の 器種名称である「クラテル」を西アジアの土器群に明確に対応させることは困難である。 アミランの分類で鉢としているものと「クラテル」としているものには，ほぼ同じ器形 が見られ，若干混乱しているようだ。本稿では，把手を有する鉢の中で, 器高が口径よ 
り大きいものを「クラテル」として認定し, 今回の分類から差し引いている。

ループ状把手付鉢は, 口唇部が内傾するタイプが北西シリアで出土していることや(第 4 図 4, 5), 口縁部や胴部がやや角張った形状を呈する夕イプが北パレスチナで出土し ている（第 4 図 7，8）といった特徵を挙げることができる。しかし $1 \cdot 2$ 類の間には, 分布上の差異，あるいは時期的な差異は確認できない。また，アミランの集成では，南 パレスチナの資料が多く使用されていたため, この器形が南パレスチナで多く分布する という印象があったが, 北パレスチナでも出土例は多く, 北西シリアまでは分布が及ん でいることを指摘したい。

\section{IV. 摘 要}

鉢形土器の四つの器形に注目し，それらの分類・分布を分析した。その結果は以下の ようにまとめられる。

(1) 外屈口縁鉢は $1 \sim 3$ 類に細分される。1 類は前 $8 \sim 7$ 世紀前半頃に属し，その分布 は北メソポ夕ミアに限定される。2 類は前 7 世紀後半以降も残り，その分布は北メソ ポタミアを中心に北西シリアに及ぶ。 3 類は前 $8 \sim 7$ 世紀前半頃に属し, 分布は北メ ソポタミアを中心とし，パレスチナではドルにのみ検出例がある。

(2) 胴部屈曲浅鉢は 1 ・2 類に細分され，1 類は北メソポタミアに分布し， 2 類はレヴァ ントを中心に一部北メソポタミアにも分布する。1 類は前 8 ～７世紀以降の検出例し かないが， 2 類は前 10 世紀後半に遡る。

(3) 棒状把手付鉢は 1 ・2 類に細分され， 1 類は前10～ 8 世紀に南パレスチナを中心に 分布し， 2 類は前 $8 \sim 7$ 世紀にパレスチナを中心に，シリアにも分布が及ぶ。北メソ ポ夕ミアにもわずかに及んでいる。

(4) ループ状把手付鉢は $1 ・ 2$ 類に細分できるが，両者とも分布はレヴァントであり， 時期は前 9 〜 世紀に属する。

\section{V. 考 察}

前 $9 \sim 7$ 世紀の北メソポタミア, シリア, パレスチナの鉢形土器の分布・分類は第 7 図のよjに図示される。この図はあくまで模式図であるので，それぞれの鉢形土器の時 期については, 上記の摘要をご覧の上, 実際には重なり合っていることをご了解いただ きたい。

本稿によって分析した 4 器形の鉢形土器は分布の偏りは見られるものの, 北メソポ夕 ミア，シリア，パレスチナにわたって分布していたり，最低でもシリアとパレスチナあ るいはシリアと北メソポタミアというようにある程度広い範囲に分布していることがわ 


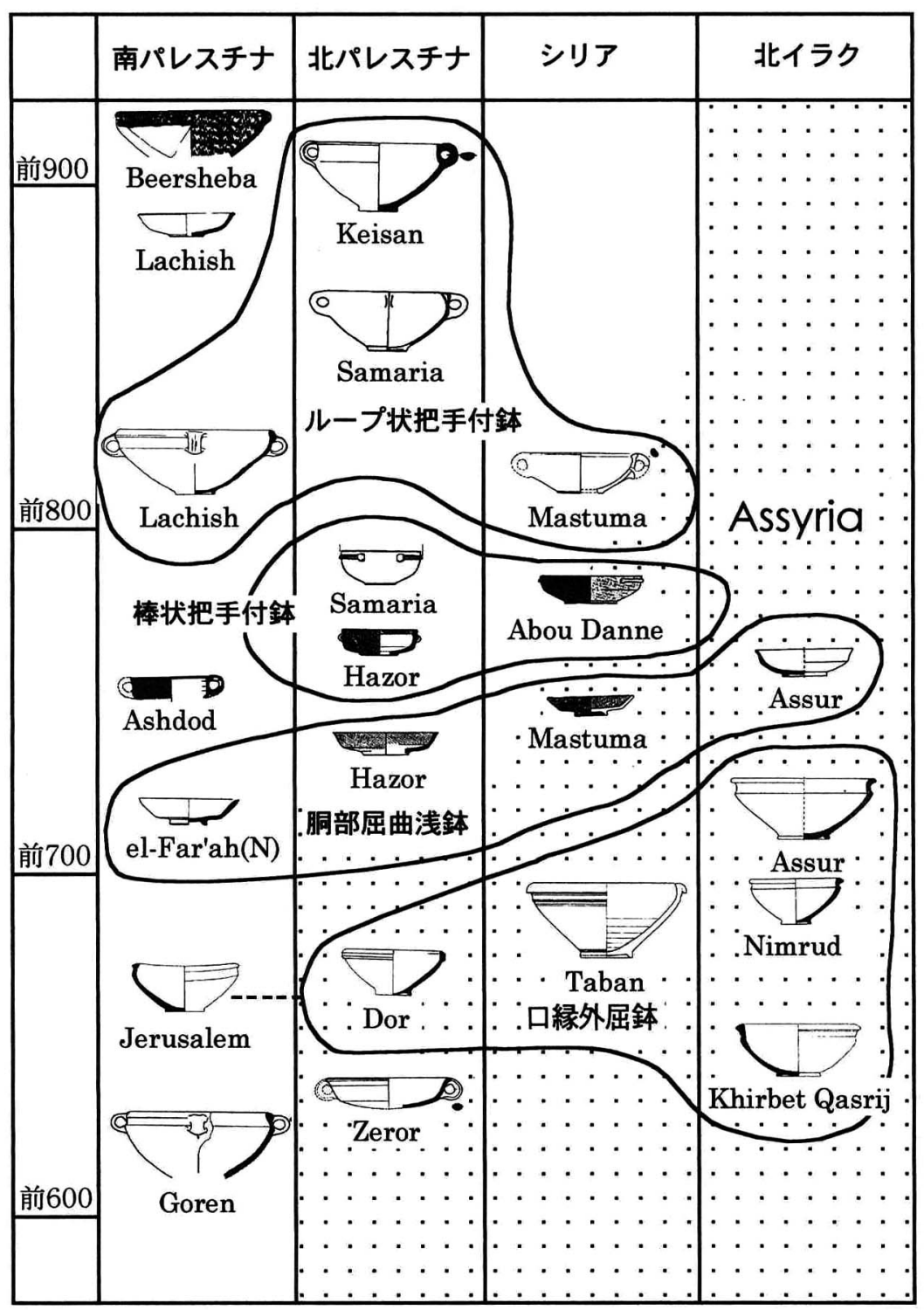

第 7 钵形土器編年模式困 
かった。つまり，本稿で分析した鉢形土器はこの時期に存在した複数の小国家の枠を越 えて分布していることになる。

筆者は鉄器時代の物質文化について，坏形土器や石製容器を対象として検討してきた が，その結論もこの時期のレヴァント地方の小国家群に共通する物質文化が認められる， (30) ということであった。この物質文化の同一性はアッシリアによるレヴァント地方の征服 以前に既に認められる。なぜこの同一性が認められるのかが，大きな課題として残って いた。そして本稿における鉢形土器の分析でも，この同一性が認められるという結果が えられたわけである。次に 4 器形についてそれぞれ考察していきたい。

まず，直接アッシリアの侵攻を表す物質文化として口縁外屈鉢に注目して，集成・分 析した。その結果, シリア, パレスチナでは散発的にしか分布しないことが明らかになっ た。パレスチナのドルではフォート・シャルマネセル出土資料とほぼ同形態の資料が存 在しており，ドルがアッシリアの拠点都市として機能していたことを裹付ける。また， 同じく口縁外屈鉢が検出されたアフィスは古代名ハズラクであり，この地域の拠点的な 都市である。イェルサレムなどでも同様な鉢形土器は検出されてるものの，北メソポ夕 ミアで見られる口縁外屈鉢とは異なる。何らかの影響を受けている可能性を考えて, 第 7 図に図示した。これらの土器の解釈については今後の課題としたい。

口縁外屈鉢は北メソポタミアでは, 典型的な後期アッシリア時代の土器群の一つであ るが，アッシリアの進行に伴い，レヴァント地方（シリア・パレスチナ）へその使用が 及んではいる。しかしレヴァント地方の分布は散発的なものに限定され，シリアではア フィス，パレスチナではドルといったアッシリアにとって拠点的な遺跡でしか検出され ていない。アッシリア人が直接居住した遺跡にのみ搬入，あるいは現地で製作されたの であろう。

後期アッシリアの物質文化として，もう一つ胴部屈曲浅鉢に注目して，集成・分析し たが，北メソポタミアとレヴァントでは，形態が異なること，またレヴァントの方が時 期的に遡る資料が検出された。そのため, 胴部屈曲浅鉢はアッシリアの拡大に伴って, レヴァントで広がった物質文化でないであろう。

このように, 後期アッシリアの典型的な土器である口縁外屈鉢・胴部屈曲浅鉢は前 $9 \sim 7$ 世紀におけるアッシリアの拡大に伴って, 北メソポ夕ミアからレヴァントに分布 が広がるということはない。ただユーフラテス河畔のティル・バルシップまでは前856年 以降アッシリアの支配が及んでおり，その後レヴァント侵攻の拠点となる場所であった のだから, 北東シリアまでは典型的な後期アッシリアの鉢形土器である口縁外屈鉢が分 布しているはずであろう。今後，この地域における口縁外屈鉢の出土例に対してさらに 注意を払っていきたい。 
パレスチナに分布の中心のある棒状把手付鉢・ループ状把手付錸はシリアまではその 分布が広がるものの，北メソポ夕ミアへはフォート・シャルマネセルの棒状把手付鉢の 類例（第 3 図12）が存在するだけである。このフォート・シャルマネセルの類例とサマ リアの類例は，前述したとおり棒状把手の形態が他と若干異なるため，今後細分できる 可能性がある。このやや形状の異なる棒状把手付鉢のみがアッシリアに属する可能性が あると考えておきたい。

アッシリアの影響が表面化してきた前 9 世紀頃には棒状把手付鉢・ループ状把手付鉢 はレヴァントに分布していた。この二つの鉢形土器はレヴァント地方固有の物質文化と して，複数の国家間にまたがって使用されていた器形であると考えることができる。ま た北メソポタミア・シリア・パレスチナという広範囲に分布する胴部屈曲浅鉢は分析結 果から判断すると, 北メソポタミアに分布する 1 類と, レヴァントに分布する 2 類に明 確に分かれており，胴部屈曲浅鉢 2 類もレヴァント地方中心の物質文化として捉えるこ とができる。

次にマストゥーマ出土の鉢形土器について考察を加えていきたい。マストゥーマ出土 の鉢形土器は胴部屈曲浅鉢 2 類とループ状把手付鉢であり，まさにレヴァント地方の物 質文化として認識できる。近距離にあるアフィスでは口縁外屈鉢 2 類が検出されており, マストゥーマでも今後の土器資料の分析が進めば，より上層 (時期が下った層位) でアッ シリアの進入を示す口縁外屈鉢が見つかる可能性はあるが，おそらく拠点的集落ではな いマストゥーマでは口縁外屈鉢は搬入あるいは現地製作されてはいないと考える。現段 階の分析ではマストゥーマは北西シリアのごく一般的な鉄器時代の町であるとみなすこ とができる。

しかし, 池田裕は, マストゥーマをハマの町の一つであるアシュタマク (Astammaku) (31)

と同定する説を紹介し，カルカルの戦いの後にハマの王イルフレニ (Irhuleni) が新しい 夏の王宮 (new summer residence) としてアシュタマクを選んだと述べている。それに 対して, 和田はマストゥーマの発掘成果から,「マストゥーマは王都ではなく,オリーブ 油の搾油や葡萄などの果汁，織物生産などで暮らしを立てていた町」と結論づけながら， マストゥーマにハマの国境警備をする要塞都市として機能を想定している。その根拠と して，マストゥーマが計画性を持って立てられた町であり，その建築プランが要塞都市 と解釈されるベールシェバとほほ同じであることを挙げている。マストゥーマの建築プ ランがベールシェバに類似することは小川英雄も指摘している。本稿の主題からそれる ので建築プランについて述べることは避けるが，マストゥーマが計画性を持った都市プ ランを有していることは事実であろう。

常木晃はマストゥーマ周辺 $10 \mathrm{~km}$ 以内に少なくとも17の鉄器時代遺跡が存在してお 
り, これらの遺跡が丘陵地に立地することを示し, 鉄器時代から丘陵地が果樹栽培の目 的で利用され始めたと指摘した。この指摘を重視するとマストゥーマは果樹栽培を目的 として計画的建設されたこの地域の町の一つであるとも考えられる。

マストゥーマは計画的に建設された町である可能性はあるが，和田と常木が指摘する ように果樹栽培を中心とした町で，政治的あるいは軍事的な拠点とは考えにくい。この ような遺跡から出土した鉢形土器の性格は，レヴァント地方に分布する夕イプのもので あり，アッシリアの影響は鉢形土器においては及んでいないと想像される。マストゥー マには大規模な破壞の痕跡も存在しないことから，アッシリアの侵入後も町は存続して いたと推定され，在地の物質文化が利用され続けたと考えられる。

\section{VI. おわりに}

鉢形土器の分析結果を考察することにより，以下 2 点の結論を得ることができた。

A. 胴部屈曲浅鉢 2 類・棒状把手付鉢・ループ状把手付鉢はレヴァント地方の小国家群 が共通して有する物質文化であった。その分布は北西シリアの一般的な町であったマ ストゥーマにも及んでいる。

B．口縁外屈鉢・胴部屈曲浅鉢 1 類は後期アッシリアの典型的な物質文化であるが，アッ シリアの拡大に伴って，その分布がレヴァント地方へ広がっていくわけではない。た とえ例外的に検出されても，それはアッシリアの拠点的な都市に限定される。

鉢形土器の一部の分析結果から得られた結論であるので，この時期の物質文化の動態 の一端を表したに過ぎない。だが，カルカルの戦いの時など一時的ではあるが，反アッ シリア同盟を結んでいた小国家群には共通する鉢形土器が分布していること(結論 $\mathrm{A}$ ), それに対して，アッシリアのレヴァント制圧後にアッシリア固有の鉢形土器は限られた アッシリア人の拠点遺跡を除いて殆ど見られないこと（結論 B） が指摘できる。ただ， この時期のレヴァント小国家は一枚岩ではなかったと考えられており, 今後さらに分析 対象を増やして, 鉢形土器に検討を加えていきながら, この時期の多様な物質文化の動 態の把握に努めていかなければならない。

付 記 本稿は，日本オリエント学会第 41 回大会における口頭発表に加筆したものです。 発表後に松本健・小口裕通・沼本宏俊 (国士舘大学イラク古代文化研究所), 大津忠彦 山内和也（中近東文化センター）・西山伸一（ロンドン大学大学院）の諸氏にご助言を いただきました。感謝申し上げます。また，国士舘大学イラク古代文化研究所・中近東 文化センターには文献収集の際，大変お世話になりました。感謝申し上げます。 
(1) R. Amiran, Ancient Pottery of the Holy Land, Massada Press Ltd, 1969.

( 2 ) G. Lehmann, "Trends in the Local Pottery Development of the Late Iron Age and Persian Period in Syria and Lebanon, ca. 700 to 300 B.C.," Bulletin of the American School of Oriental Research 311(1998): 7-37.

(3) H. Wada, "Pottery Vessels in the Iron Age I in the South Area in Tell Mastuma," Bulletin of the Ancient Orient Museum 15 (1994): 51-76 ; 和田久彦「テル・ マストゥーマの現地整理」『第 5 回西アジア発掘調査報告会・報告集』古代オリエント 博物館, 1998: 42-46.

（4）斎藤信弘「北シリア鉄器時代の搬入土器一Syria: Tell Mastuma の事例から一」 立教大学大学院文学研究科地理学専攻博士前期課程論文, 1996.

（5）四角隆二「(研究ノート)いわゆるケルノス・リングについて」『青山考古』14(1997): 77-86.

（6）足立拓朗「レヴァント鉄器時代のキャリネイションを有する精製坏形土器」『青山 考古』15(1998): 67-82; T. Adachi, “The Fine Carinated Bowl in the Iron Age," Bulletin of the Ancient Orient Museum 18(1997): 41-56.

( 7 ) J. Lines, "Late Assyrian Pottery from Nimrud," Iraq 16 (1954): 164-167; J. Oates, "Late Assyrian Pottery from Fort Shalmaneser," Iraq 21 (1959): 130-146.

(8) J. Curtis et al., Excavations at Qasrij Cliff and Khirbet Qasrij, Trustees of the British Museum, London, 1989; J.Curtis \& A. Green, Excavations at Khirbet Khatuniyeh, Trustees of the British Museum, London, 1997.

( 9 ) T. Ohtsu, "Late Assyrian 'Pallace Ware': Concerning Dimpled Goblet," Bulletin of the Middle Eastern Culture Center in Japan 4 (1991): 131-153.

(10) Lines, op.cit.: 165.

(11) Ibid.

(12) Oates, op.cit:: 132.

(13) Lines, loc.cit:; Oates, op, cit.: 141.

(14) Lehmann, op.cit:: 21.

(15) Amiran, op.cit: : 195-206.

(16) Ibid.

(17) Ibid: 201.

（18）Ibid:: 205。ループ状把手付鉢を南部地域のみ掲載している。ただし，ほほ同じ器 形の「クラテル」が北部で出土していることを示している (ibid:: 223)。

(19) Lines, loc.cit; Oates, op.cit:: 147.

(20) Curtis et al., op.cit.: 18, 51-53; Curtis \& Green, op.cit.: 9-13; H. Fujii et al., "Preliminary Report on the Excavations at Tell Thuwaij, Tell Jessary (second season), and Qasr Banat," Sumer 46(1989-90): 38-59. 
(21) A. Haller, Die Gräer und Grüte von Assur, WDOG-G 65, Berlin, 1954; K. Ohnuma et al., "Excavation at Tell Taban, Hassake, Syria: Report of the 1997 Season of Work," Al-Rafidan (Institute for Culture Studies of Ancient Iraq, Tokyo), 20 (1998): 1-21.

(22) C. Postage et al., The Excavations at Tell al Rimah: The Pottery, British School of Archaeology in Iraq, 1997; E. Klengel-Brandt, "Vorläfiger Bericht über die Ausgrabungen des Vorderasiatischen Ergebnisse der Kampagnen 1993 und 1994," MDOG 128(1996): 33-67.

(23）オーツにより有溝折り返し口縁 (grooved folded rim) を有するタイプと分類され ている (Oates, op.cit:: 140)。

(24) S. M. Cecchini, “Area G. The Iron Age I-III Levels Architecture, Pottery and Finds," in S. M. Cecchini et al.(eds.), Tell Afis (Syria): The 1988-1992 Evacuations on the Acropolis, Edizioni Ets, Pisa, 1998: 273-365, Fig.35-21.

(25) A. Gilboa, "Assyrian-Type at Dor and the Status of the Town during the Assyrian Occupation Period," Eretz-israel 25 (1996): 92, 122-135.

(26) Amiran, loc.cit.

(27) Ibid:: 15-18,19,20.

（28）大津忠彦は「クラテール」を「中近東では，深い鉢あるいは盇の総称」と捉えてい る。大津忠彦「古代地中海沿岸地域における土器型式学一考古学的「器形」と文献史 料に記された名称一」『考古学雑誌』82/4 (1997): 59-77.

(29) Amiran, op.cit:: 200-206.

(30) T. Adachi, “The Fine Carinated Bowl in the Iron Age," BAOM 18(1997): 41-56

(52-54); 足立拓朗「レバント鉄器時代の石製容器」『オリエント』41/1(1998): 141-156 (152-154) .

(31) Y. Ikeda, “Royal Cities and Fortified Cities,” Iraq 41/1(1979): 75-87(79).

(32) Ibid: 83 .

（33）和田久彦「アシュタマクとその時代（その1)」『オリエンテ』15 (1997): 19-23.

(34) 上掲論文, 20頁.

（35）小川英雄・山本由美子『世界の歴史 4 オリエント世界の発展』中央公論社, 1997 ： 75.

(36) A. Tsuneki, "3. General Survey of Tells around Tell Mastuma," in Sh. Wakita, "Tell Mastuma: A Preliminary Report of the Excavations in Idlib, Syria, 1993,” BAOM 15(1994): 31-32.

（37）和田久彦「アシュタマクとその時代 (その 2)」『オリエンテ』16(1997)：18-22 (22).

(38) H.クレンゲル『古代シリアの歴史と文化 東西文化のかけ橋』五味亨訳, 六興出 版, $1991: 226$. 


\section{挿図出典}

第1-1図 Lines, op.cit.: P1.XXXVII-5; 第1-2図 Curtis et al., op.cit.: Fig.24-30; 第1-3図 Oates, op.cit: P1.XXXV-24; 第1-4図 Haller, op.cit:: Tafel 6-m; 第1-5図 Curtis et al., op.cit: Fig.8-17; 第1-6図 Gilboa, op.cit: p.128, Fig.3-10; 第1-7図 Oates, op.cit: P1. XXXV-25; 第1-8図 Ohnuma, op.cit: Fig.8-11; 第1-9図 I. Eshel, “Two Pottery Groups from Kenyon's Excavations on the Eastern Slope of Ancient Jerusalem," in I. Eshel et al. (eds.), Excavations by K. M. Kenyon in Jerusalem 1961-1961, Oxford University Press, Oxford, 1995: 1-158, Fig.14-19; 第1-10园 K. Yassine, Tell el Mazar I Cemetary A, University of Jordan, 1984: Fig.3-8; 第1-11図 B. Hrouda, Tell Halaf, Walter de Gruyter \& Co., Berlin, 1962: Tafel 61-151; 第2-1図 Haller, op.cit.: Tafel 6-ag; 第2-2図 Lines, op.cit: P1.XXXVII-3; 第2-3図 W. E. Rast, Taanach I: Studies in the Iron Age Pottery, American Schools of Oriental Research, Cambridge, 1978: Fig.52-6; 第2-4図 Y. Aharoni, Investigations at Lachish: The Sanctuary and the Residency (Lachish V), Tel Aviv University, Tel Aviv, 1975: Pl.44-1; 第2-5図 F. James, The Iron Age at Beth Shan: A Study of Levels VI-IV, University Museum, University of Pennsylvania: Fig.63-11; 第2-6図 Y. Yadin et al., Hazor III-IV: An Account of the Third and Fourth Season of Excavations, 1957-1958, Hebrew University, Jerusalem, 1961: Pl.CLXXXI-1; 第2-7図 Lehmann, op.cit: Fig.7-7; 第2-8 図 Eshel, op.cit: Fig.12-2; 第2-9図 Sh. Wakita, “Tell Mastuma: A preliminary Report of the Excavations at Idlib, Syria, in 1994 and 1995," BAOM 16(1995): 1-74, Fig.7-4; 第2-10図 A. Chambon, Tell el-Far'ah I: L'âge du Fer, Recherche sur les civilisations, Paris, 1984: P1.58-14; 第3-1図 Amiran, op.cit: P1.63-8; 第3-2図 Yadin et al., op.cit:: Pl.CLXXXII-13; 第3-3図 Z. Herzog, Beer-Sheba II: The Early Iron Age Settlements, Tel Aviv University, Tel Aviv, 1984: Fig.26-8; 第3-4図 M. Dothan, "Ashdod II-III: The Second and Third Seasons of Excavations 1963, 1965," Atiqot 4/10(1971): Fig.52-22; 第3-5図 Yadin et al., op.cit.: Pl.CCXIX-9; 第3-6図 J. Briend et al., Tell Keisan (1971-1976): Une cité phénicienne en Galilée, Editions Universitaires Fribourg Sisse, Paris, 1980: Pl.53-12; 第3-7図 Yadin et al., op.cit: P1. CCXXVI-12; 第3-8図 Y. Yadin, Hazor II: An Account of the Second Season of Excavations, 1956, Hebrew University, Jerusalem, 1960: P1.XCVIII-27; 第3-9図 Yadin et al., op.cit.: P1.CCXXVI-10; 第3-10図 J. Crowfoot, Samaria-Sebeste, London, 1957: Fig.16-2; 第3-11図 ibid.: Fig.16-1; 第3-12図 Oates, op.cit: P1.XXXV-24; 第 3-13図 Chambon, op.cit.: P1.56-5; 第3-14図 M. Lebeau, La Céramique de l'âge du Fer II-III à Tell Abou Danné, Editions Recherche sur les civilisations, Paris, 1983: Pl. XIV-4; 第4-1図 Dothan, op.cit.: Fig.5-13; 第4-2図 Herzog, op.cit.: Fig.27-10; 第4-3図 Chambon, op.cit:: Pl.56-2; 第4-4図 P. J. Riis et al., Hama, Fouilles et Recherches 1931-1938, II-2, Copenhague, 1990: Fig.78-593; 第4-5図 N.Egami et al., Tell 
Mastuma Excavations in Idlib District, Syria, 1982, Ancient Orient Museum, Tokyo, 1984: P1.6-10; 第4-6図 K. Ohata(ed.), Tel Zeror III, Society for Near Eastern Studies in Japan, 1970: Pl.XV-4; 第4-7図 Yadin, op.cit: Pl.XCVIII-43; 第4-8図 Briend et al., op.cit.: P1.78-1; 第4-9図 Aharoni, op.cit.: Pl.41-9; 第4-10図 B. Mazar et al., "En-Gedi: The First and Second Seasons of Excavations 1961-1962," Atiqot (Jerusalem Academic Press), 1960: Fig.16-5. 